\title{
The Viability of Winter Sporangia of Synchytrium endobioticum (Schilb.) Perc. from Poland
}

\author{
Jaroslaw Przetakiewicz ${ }^{1}$
}

Published online: 11 November 2015

(C) The Author(s) 2015. This article is published with open access at Springerlink.com

\begin{abstract}
The longevity, infectivity and virulence of winter sporangia of Synchytrium endobioticum, the causal agent of potato wart disease, were studied in soil collected from an infested plot 43 years since the last observed infection. The demarcated plot was located in a mountainous area of the central part of Sudetes Mountain range in Poland and no potatoes were grown in the plots over that period. Sporangia of S. endobioticum were collected from the samples and retained viability after 46 years. Infectivity of the fungus was tested using modified Potoček's tube test. The ability of the spores to invade and replicate in potato host tissue was demonstrated using sporangia collected after 43 years. The virulence of the obtained isolates was tested with the Glynne-Lemmerzal method. Two different pathotypes were identified: 1(D1), the most widely distributed in Europe and 3(M1), a unique Polish local pathotype, which was isolated and identified for the first time from the same location in 1965.
\end{abstract}

Resumen Se estudió la longevidad, infectividad y virulencia de esporangia invernante de Synchitrium endobioticum, el agente causante de la verruga de la papa, en suelo colectado de un lote infestado por 43 años desde que se observó la última infección. El lote marcado se localizó en un área montañosa de la parte central de la montaña Sudetes en Polonia y no se cultivaron papas en los lotes en ese período. Se colectó esporangia de $S$. endobioticum de las muestras y retuvieron la viabilidad después de 46 años. Se probó la infectividad del hongo utilizando una prueba modificada de

Jaroslaw Przetakiewicz

j.przetakiewicz@ihar.edu.pl

1 Plant Breeding and Acclimatization Institute - National Research Institute, Radzikow 05-870, Blonie, Poland tubo de Potoček. Se demostró la habilidad de las esporas para invadir y replicarse en el tejido de la papa hospedante utilizando esporangia colectada después de 43 años. Se probó la virulencia de los aislamientos obtenidos con el método Glynne-Lemmerzal. Se identificaron dos diferentes patotipos: 1(D1), el más ampliamente distribuido en Europa, y el 3(M1), un patotipo local único polaco, que se aisló e identificó por primera vez de la misma localidad en 1965.

Keywords Synchytrium endobioticum · Potato wart disease . Longevity $\cdot$ Infectivity and virulence of the spores

\section{Introduction}

Potato is one of the most important crops worldwide and the fourth-largest food crop, following maize, wheat and rice. In the European Union, potatoes are produced on approximately 2 million ha. The main growing areas are located in Poland, Germany, Romania, France, the Netherlands, and the United Kingdom (Flath et al. 2014). Synchytrium endobioticum is an obligate soil-borne biotrophic fungus that causes potato wart disease which is one of the major quarantine diseases in Europe (EPPO 2004). The pathogen originated from the Andean region of South America (Hampson 1993), but now has worldwide distribution (EPPO/CABI 1996). Potato wart occurs in almost all European countries on a regional basis. Cultivated potato is the primary host, but the fungus can also infect wild species of Solanum. Synchytrium endobioticum infects epidermal cells of all meristematic tissues of potato except roots. Its long persistence in soil and the severe losses it inflicts to potato crops have prompted its inclusion into the A2 quarantine list (EPPO/CABI 1996). Winter (resting) sporangia are the dormant structures by which the fungus disperses to establish new infections. Thick-walled winter 
sporangia, can survive for a long time without plant hosts (Steinmöller et al. 2012), even through adverse condition (Hooker 1981).

Different reports indicated that the pathogen might survive in soil for up to 10 to 40 years (Noble and Glynne 1970; McDonnell and Kavanagh 1980; Putnam and Sindermann 1994; Laidlaw 1985). The reports include observations of disease recurrence in field, or on direct examination of the spores, rather than experimental determination of an end point to spore viability and infection ability.

In Poland, different pathotypes of $S$. endobioticum occur mainly in the rainy mountainous areas of Sudetes and Carpathians. They persist mainly in small garden potato plots, in economically unimportant potato-growing regions but still very important for quarantine and phytosanitary measures as spores can spread in rain water. The economic impact of disease caused by this pathogen is not only from disease losses but from loss of international trade markets, long-term quarantines, and regulatory restrictions placed on infested areas and the buffer zones (Przetakiewicz 2014a).

The Polish pathotype 3(M1) of S. endobioticum was first identified in 1965 from diseased plants in southern Poland (Malec 1981). After a recorded occurrence of S. endobioticum The Polish Plant Health and Seed Inspection Service (PIORiN) demarcated the contaminated plot and a safety buffer zone. Potato production was prevented at that location with the application of strict quarantine measures for 48 years. The location remains the oldest area contaminated by the resting spores of pathotype 3(M1) in Poland.

The aim of the research presented here was not only to confirm viability of the spores older than 40 years, but also to assess how long the viable spores retain the ability to invade and replicate in potato as well as to retain the virulence previously found on the contaminated plot.

\section{Materials and Methods}

In 2007, soil was sampled by PIORiN, according to the EPPO standard PM 3/59 (EPPO 1999), from the quarantined area in the Lower Silesian District of the southern part of Poland. The infested field was located in the central part of Sudetes Mountain. Winter sporangia from soil were isolated using wet-sieving method of Pratt (1976). Viability of winter sporangia was determined by microscopic examination of sporangia in water. According to Pratt (1976), winter sporangia of $S$. endobioticum were viable if they were filled with greyish granular contents, or not viable if plasmolysed (dead) and with no apparent content (dead). These were counted according to manufacturer's instructions using a FuchsRosenthal counting chamber. Bioassays with susceptible potatoes in modified Potoček's tube tests were used (Potoček et al. 1991). In the test, infested soil was replaced by concentrated inoculum. Concentrating of inoculum density was done by centrifugation of the spores extracted from soil by wet sieving and decanting. Inoculum $(10.0 \mathrm{ml})$ was obtained from $1 \mathrm{~kg}$ of soil. On the top of each tuber a plastic ring (2 $\mathrm{cm}$ high and $3 \mathrm{~cm}$ in diameter) was fixed using warm paraffin. Each ring was filled with sterile river sand up to $1.5 \mathrm{~cm}$ depth. One milliliter of inoculum was pipetted into each of 10 rings of potato genotype ' 1169 ' which is extremely susceptible to all known pathotypes of S. endobioticum. The inoculated tubers with rings were moistened, and placed in plastic box at $16-18{ }^{\circ} \mathrm{C}$ in the dark. The sand in the rings was moistened daily with distilled water to maintain sufficient moisture. During incubation, the sprouts were cut down at the upper edge of the rings. After 14 days of incubation, new sprouts were examined under the stereoscopic microscope. If no potato wart disease was observed, the sprouts were cut down. If proliferation of the sprouts was observed, the tuber with ring was kept in the sand under the same conditions as described above for wart production. After 4-6 weeks the largest warts were multiplied using modified GlynneLemmerzahl method (Przetakiewicz 2008). The virulence of the fungus was determined on a set of differential potato cultivars, recommended by EPPO standard PM 7/28 (EPPO 2004) and others used to distinguish the local Polish pathotypes (Table 1).

\section{Results and Discussion}

Microscopic examinations of soil sample confirmed the presence of winter sporangia of Synchytrium endobioticum. The spores were spherical to ovoid in shape with thick-walled (triple wall) structure, which was ornamented with irregularly shaped wing-like protrusions. Microscopic assessment revealed that most of winter sporangia were empty or plasmolysed but single spores were still filled with greyish granular content. In 2007, ten viable spores per $1 \mathrm{~kg}$ of soil were detected. Viable spore numbers decreased during detection since the last 6 years of survey, from 10 to 0 in 2007 and 2012 , respectively. In 2008, galls on the newly grown sprouts were observed on 2 out of 10 tubers after application of modified Potoček's tube test. The first proliferation of tissue was observed on sprouts after 45 days incubation (Fig. 1a). Direct examination under stereoscopic and light microscope confirmed the presence of characteristic sori with summer sporangia of $S$. endobioticum (Fig. 1c). Fourteen days later (59 days after inoculation) the next proliferation was observed on sprouts of other tubers. During 4-6 weeks of incubation the galls grew sufficiently to use for multiplication and pathotype identification (Fig. 1b). Two isolates of S. endobioticum (\#28/ 2007/1 and \#28/2007/2) were determined separately. The Potoček's tube test was conducted through the years 2008 2012 , but the disease symptoms could be initiated only in 
Table 1 Reaction of differential cultivars of potato to infection with pathotypes, occurring in Poland, and with isolates of $\mathrm{S}$. endobioticum obtained from resting spores after 43 years dormancy

\begin{tabular}{llllllll}
\hline Cultivars & \multicolumn{2}{l}{ Pathotypes \& isolates } & & & \\
\cline { 2 - 7 } & $1(\mathrm{D} 1)$ & $2(\mathrm{Ch} 1)$ & $3(\mathrm{M} 1)$ & $18(\mathrm{~T} 1)$ & $39(\mathrm{P} 1)$ & $\# 28 / 2007 / 1$ & $\# 28 / 2007 / 2$ \\
\hline Deodara & $\mathrm{S} 2_{\mathrm{b}}$ & $\mathrm{S} 2$ & $\mathrm{~S} 2$ & $\mathrm{~S} 2$ & $\mathrm{~S} 2$ & $\mathrm{~S} 2$ & $\mathrm{~S} 2$ \\
Tomensa & $\mathrm{S} 2$ & $\mathrm{~S} 2$ & $\mathrm{~S} 2$ & $\mathrm{~S} 2$ & $\mathrm{~S} 2$ & $\mathrm{~S} 2$ & $\mathrm{~S} 2$ \\
Eersteling & $\mathrm{S} 2$ & $\mathrm{~S} 2$ & $\mathrm{~S} 2$ & $\mathrm{~S} 2$ & $\mathrm{~S} 2$ & $\mathrm{~S} 2$ & $\mathrm{~S} 2$ \\
Producent & $\mathrm{R}$ & $\mathrm{S} 2$ & $\mathrm{~S} 2$ & $\mathrm{~S} 2$ & $\mathrm{~S} 2$ & $\mathrm{~S} 2$ & $\mathrm{R}$ \\
Combi & $\mathrm{R}$ & $\mathrm{S} 2$ & $\mathrm{~S} 2$ & $\mathrm{~S} 2$ & $\mathrm{~S} 2$ & $\mathrm{~S} 2$ & $\mathrm{R}$ \\
Delcora & $\mathrm{R}$ & $\mathrm{S} 1$ & $\mathrm{~S} 1$ & $\mathrm{~S} 2$ & $\mathrm{~S} 2$ & $\mathrm{~S} 1$ & $\mathrm{R}$ \\
Saphir & $\mathrm{R}$ & $\mathrm{R}$ & $\mathrm{R}$ & $\mathrm{R}$ & $\mathrm{R}$ & $\mathrm{R}$ & $\mathrm{R}$ \\
Miriam & $\mathrm{R}$ & $\mathrm{S} 1$ & $\mathrm{~S} 1$ & $\mathrm{~S} 2$ & $\mathrm{~S} 2$ & $\mathrm{~S} 1$ & $\mathrm{R}$ \\
Karolin & $\mathrm{R}$ & $\mathrm{R}$ & $\mathrm{R}$ & $\mathrm{R}$ & $\mathrm{S} 1$ & $\mathrm{R}$ & $\mathrm{R}$ \\
Ulme & $\mathrm{R}$ & $\mathrm{R}$ & $\mathrm{R}$ & $\mathrm{R}$ & $\mathrm{R}$ & $\mathrm{R}$ & $\mathrm{R}$ \\
Sissi & $\mathrm{R}$ & $\mathrm{S} 1$ & $\mathrm{~S} 1$ & $\mathrm{~S} 2$ & $\mathrm{~S} 1$ & $\mathrm{~S} 1$ & $\mathrm{R}$ \\
Désirée & $\mathrm{R}$ & $\mathrm{S} 2$ & $\mathrm{~S} 1$ & $\mathrm{~S} 2$ & $\mathrm{~S} 1$ & $\mathrm{~S} 1$ & $\mathrm{R}$ \\
Asche Sämling & $\mathrm{S} 2$ & $\mathrm{~S} 1$ & $\mathrm{~S} 2$ & $\mathrm{~S} 2$ & $\mathrm{~S} 1$ & $\mathrm{~S} 2$ & $\mathrm{~S} 2$ \\
\hline
\end{tabular}

a 1(D1) - recorded in 1917 (Grabowski 1925); 2(Ch1) - in 1961 (Malec 1981), 3(M1) - in 1965 (Malec 1981), 18(T1) - in 2008 (Przetakiewicz 2014b) and 39(P1) - in 2009 (Przetakiewicz 2015)

b Classification of reaction types was carried out, according to Flath et al. 2014: S2 - extremely susceptible (predominant tumor formation); S1 - weakly susceptible (scattered infections, sprout can be slightly malformed, presentation of winter sporangia); R (R1 and R2) - resistant (early, late and very late defense necrosis are visible, no winter sporangia)
2008. Table 1 shows the results of the reaction of differential cultivars to isolate \#28/2007-1 and \#28/2007-2 as well as to reference pathotypes occurring in Poland: 1(D1), 2(Ch1), 3(M1), 18(T1) and 39(P1). Based on the results, it was confirmed that isolate $\# 28 / 2007 / 1$ belongs to pathotype 3(M1), which was discovered for the first time in the same plot in 1965 , and \#28/2007/2 which belongs to pathotype 1(D1), first detected in Poland in 1917.

Due to the fact that winter sporangia of $S$. endobioticum can remain viable for 30-40 years (Laidlaw 1985), soil samples were collected from an older plot (known as the oldest plot in Poland) for verification of viability of the spores. For almost 50 years, quarantine and domestic legislation have been in force to prevent its spread from the infested field.
The viability of the spores remaining in soil for 46 years was confirmed by direct examination of the soil. The sporangium wall contains fatty acids and wax esters which serves as a protective device for continued viability of S. endobioticum in the soil (Bal et al. 1984). The mature wall of winter sporangia with compact layers of oriented chitin microfibrils serve as a protective cover, which may enhance its survival characteristics (Murphy et al. 1981). Additionally, longevity of the spores may be influenced by the damp cool climate of southern Poland as this kind of climate is more suitable for the pathogen as suggested by Bojnansky (1968). The cold climate of Polish highlands and high plateaus has an average temperature of about $10{ }^{\circ} \mathrm{C}$ in the warmest months, and averages below

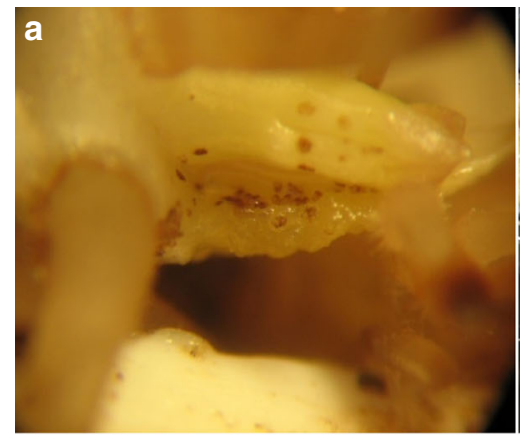

Fig. 1 The symptoms of potato wart disease obtained from winter spores of Synchytrium endobioticum after 43 years dormancy. The first sori a) appeared on sprout after 45 days incubation. More than 7 weeks later a
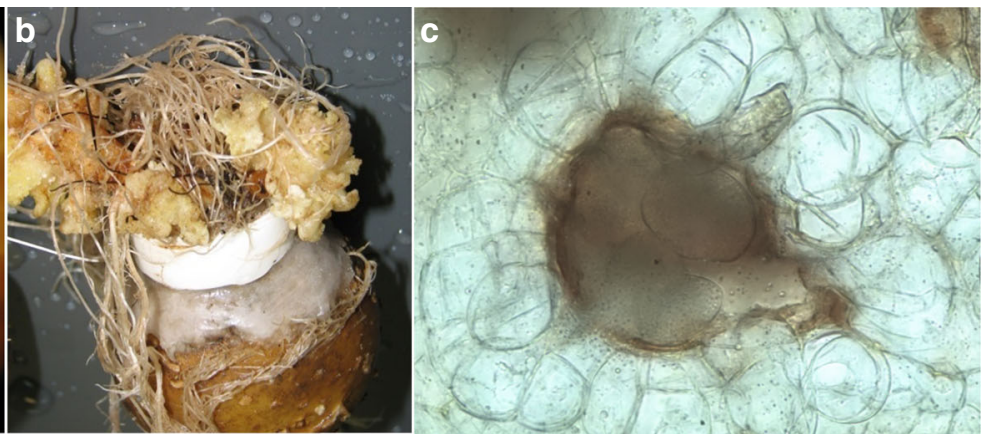

predominant tumor formation b) was observed. Direct microscopic examination confirmed the presence of summer sporangia in the sorus c) Magnification of $\times 1000$ 
$-3{ }^{\circ} \mathrm{C}$ in the coldest months. Long and cold winters inhibit the germination of the spores in contrary to climate of Western Europe when the warm Gulf stream conditioning mild winters promotes the germination of a higher percentage of winter sporangia, which encourages eradication of the pathogen in inter-host periods. Nevertheless, even in favorable conditions, only a small percentage of the sporangia present may germinate (Lange and Olson 1981). The low and irregular rate of germination may account in part for the longevity and may be a main survival strategy of $S$. endobioticum.

In this study the germination and infectivity of the spores were determined indirectly by observation of wart incidence. A positive result of the bioassays was considered as sufficient proof for the ability of spores to germinate and to invade and replicate in the host. Although no method for reliable stimulation of germination of the spores has been found so far (Lange and Olson 1981), according to Hartman (1955) high moisture and temperature of $16-17^{\circ} \mathrm{C}$ are the most suitable for infection and development of $S$. endobioticum under field conditions. Such conditions are produced in the modified Potoček's tube test. At least two out of all isolated viable spores were able to release zoospores through the years 2008-2012 as confirmed by development of the galls on potato sprouts. After 43 years, in favourable conditions, disease recurrence may occur even from single spores of $S$. endobioticum.

Pathotype identification revealed the occurrence of two different pathotypes [3(M1) and 1(D1)] in the same contaminated plot. According to Malec (1963), the virulence of pathotype 1(D1) of $S$. endobioticum may increase due to "passaging" on slightly susceptible cultivars of potato. Therefore, the presence of resting spores of the fungus, belonging to pathotype 1(D1) and another one, simultaneously in the same plot is possible. In 1965, warted tubers of pathotype 3(M1) were found on cultivars resistant to pathotype 1(D1) (Malec 1981). This led to the suggestion that isolate $\# 28 / 2007 / 2$ was obtained from sporangia older than even 43 years, but the cropping history of the field before 1965 was unknown.

In 2012, no viable winter sporangia were detected in the plot, after an official survey by the PIORiN. In 2013, the infested field was completely de-scheduled. Revoking the demarcation of the contaminated plot was justified after 47 years. Based on the results obtained in this study, it was concluded that winter sporangia of $S$. endobioticum are very persistent and capable of retaining viability for as long as 46 years. The single spores from the inter-host period were still infective after 43 years. The virulence of the isolates corresponds to the behavior of the pathotypes that originated from the same location. Consequently these results should be taken into consideration when de-scheduling previously infested plots even after 40 years or longer, especially in the mountainous areas of Poland.
Open Access This article is distributed under the terms of the Creative Commons Attribution 4.0 International License (http:// creativecommons.org/licenses/by/4.0/), which permits unrestricted use, distribution, and reproduction in any medium, provided you give appropriate credit to the original author(s) and the source, provide a link to the Creative Commons license, and indicate if changes were made.

\section{References}

Bal, A.K., A.C. Dey, and M.C. Hampson. 1984. Resting sporangium of Synchytrium endobioticum: its structure and composition of the lipids and fatty acids. Archives of Microbiology 140: 178-182.

Bojnansky, V. 1968. The effect of soil type on the development and severity of potato wart disease. E. Potato Journal 11: 100-110.

EPPO. 1999. EPPO standards PM 3/59 Synchytrium endobioticum: soil tests and de-scheduling of previously infested plots. Bull OEPP/ EPPO Bull 29: 225-231.

EPPO. 2004. EPPO standards PM 7/28 Synchytrium endobioticum. Bull OEPP/EPPO Bull 34: 213-218.

EPPO/CABI. 1996. Synchytrium endobioticum. In quarantine pests for Europe, 2nd ed. Wallingford: CAB International.

Flath, K., J. Przetakiewicz, P.C.J. van Rijswick, V. Ristau, and G.C.M. van Leeuwen. 2014. Interlaboratory tests for resistance to Synchytrium endobioticum in potato by the Glynne-Lemmerzahl method. OEPP/EPPO Bulletin 44: 510-517.

Grabowski, L. 1925. Potato wart /Synchytrium endibioticum Perc./ in Poland. Choroby i Szkodniki Roślin 2: 1-14.

Hampson, M.C. 1993. History, biology and control of potato wart disease in Canada. Canadian Journal of Plant Pathology 15: 223-244.

Hartman, R.E. 1955. Potato wart eradication program in Pensylvania. American Potato Journal 23: 317-326.

Hooker, W.J. (ed.). 1981. Compendium of potato disease, 125. Minnesota: Am. Phytopatgol. Society, St. Paul.

Laidlaw, W.M.R. 1985. A method for the detection of the resting sporangia of potato wart disease (Synchytrium endobioticum) in the soil of old outbreak sites. Potato Research 28: 223-232.

Lange, L., and W.L. Olson. 1981. Germination and Parasidation of the Resting Sporangia of Synchytrium endobioticum. Protoplasma 106: 69-82.

Malec, K. 1963. Changes in the virulence of fungus Synchytrium endobioticum (Schilb.) Perc. depending on the degree of susceptibility of potato cultivars and to the date of infection. Hod Rośl Aklim Nasienn 7: 25-54.

Malec, K. 1981. Pathotypes of Synchytrium endobioticum) Schilb. (Perc.) in Poland. 1-38. Instytut Ziemniaka, Bonin.

McDonnell, M.B. and J.A. Kavanagh. 1980. Studies on Synchytrium endobioticum (Schilb.) Perc. In Ireland. Journal of Life Sciences, Royal Dublin Society 1(2):177-182.

Murphy, A.M., A.K. Bal, and M.C. Hampson. 1981. Incorporation of uridine diphospho-N-acetyl-D-glucosamine in the resting sporangium wall of Synchytrium endobioticum. Experientia 38: 244-246.

Noble, M., and Glynne. 1970. Wart disease of potatoes. FAO Plant Protection Bulletin 18: 125-135.

Potoček, J., V. Gaar, M. Hnizdil, and F. Novak. 1991. Protection against spreading of potato wart disease and potato cyst nematode. Metodiky ÚVTIZ 18: 88 .

Pratt, M.A. 1976. A wet-sieving and floating technique for the detection of resting sporangia of Synchytrium endobioticum in soil. Annals of Applied Biology 82: 21-29.

Przetakiewicz, J. 2008. Assessment of the resistance of potato cultivars to Synchytrium endobioticum (Schilb.) Per. in Poland. Bull OEPP/ EPPO Bull 38: 211-215. 
Przetakiewicz, J. 2014a. Manual of security sensitive microbes and toxins: Synchytrium endobioticum, ed. Dong Liu, 823-829. Boca Raton: CRC Press.

Przetakiewicz, J. 2014b. First report of Synchytrium endobioticum (potato wart disease) pathotype 18(T1) in Poland. Plant Disease 98: 688.

Przetakiewicz, J. 2015. First report of new pathotype 39(P1) of Synchytrium endobioticum causing potato wart disease in Poland. Plant Disease 99: 285.2.
Putnam, M.L., and A.B. Sindermann. 1994. Eradication of potato wart disease from Maryland. American Potato Journal 71: 743-747.

Steinmöller, S., M. Bandte, C. Büttner, and P. Müller. 2012. Effects of sanitation processes on survival of Synchytrium endobioticum and Globodera rostochiensis. European Journal of Plant Pathology 133: 753-763. 